\title{
Cooperative Sustainability Analysis from the Perspective of Entrepreneurial Personality and Entrepreneurial Intention
}

\author{
Artarina D. A. Samoedra* \\ Widyatama University \& Universitas Pendidikan Indonesia, Jl.Cikutra No.204A, 40132, Bandung, Indonesia
}

\begin{abstract}
Objective - This paper analyses the sustainability of cooperatives in the West-Bandung Regency from the perspective of entrepreneurial personality and intention. The aim of this paper is to see whether the viability of cooperative can still be maintained and whether it can still be taken as the foundation of the people's economy, seen from the perspective of the aspect of its members' entrepreneurship.

Methodology/Technique - The method used is quantitative in nature using the Structural Equation Model (SEM) as the tool of analysis.

Findings - The results show that the variable with the highest influence is entrepreneurial personality on intention, and the variable with the lowest influence is entrepreneurial intention on value creation.

Novelty - This paper holds strong implications with one indicating that the regional government is strongly advised to facilitate and guide cooperative sustainability through formal programs such as through guided consultations on cooperative management or through seminars, workshops and trainings to develop qualified cooperative members.
\end{abstract}

Type of Paper: Empirical

Keywords: Cooperative; Sustainability; Entrepreneurial Personality; Entrepreneurial Intention.

JEL Classification: L20, L26.

\section{Introduction}

A cooperative has an unusual management system that is known as "from the people to the people" or "from the members to the members" which means that everything that has something to do with the cooperative is decided by its own members. Nevertheless, the current development of cooperatives in Indonesia is in an erratic stage. Based on this fact, it is important to improve and reshape the performance of cooperatives. From the data provided by Dr. Asep Ruhimat, Head of Cooperation of SMEs, Disperindagkop and West Bandung regency, the number of cooperatives that currently exist is around 823 and of these, only $46 \%$ can be categorized as healthy with the remaining $54 \%$ still needing guidance and assistance in carrying out cooperative activities periodically. The West Bandung regency consists of cooperatives which aim to act as a provider of new jobs for rural communities, thus, they are important players in the local economic activities and community development. Cooperatives build and develop the potential and ability of member economies

\footnotetext{
* Paper Info: Received: September 14, 2016

Accepted: December 11, 2016

* Corresponding author:

E-mail: artarina.dewi@widyatama.ac.id

Affiliation: Widyatama University \& Universitas Pendidikan Indonesia, Bandung, Indonesia
} 
as well as the local people to improve their economic and social welfare. Cooperatives also enable the local people to strengthen their economy by acting as the basis of national strength and resilience as well as sources of innovation.

Nonetheless, cooperatives today are facing various obstacles, both from internal and external aspects, particularly in the West-Bandung regency. Here, the banking sector is still dominant in the people's economy but there are a lot of devious moneylenders who are disguised as cooperatives. The fundamental problem is that the local people's knowledge and awareness concerning the potential benefits which can be derived from cooperatives is still deficient, including among those who have become active members. This lack of knowledge, in turn, causes many existing cooperatives to function less effectively as they are regulated by the current economic regulations. Therefore, it is difficult for cooperatives to grow or even to survive.

In dealing with the acute problems plaguing this economic institution, the cooperatives in West-Bandung Regency are employing two approaches which have been implemented before. The first approach is a practical one. It has always been used by the regional government of the West-Bandung Regency through DISPERINDAG (the council of trade and manufacture) and UMKM (small and medium enterprises), which provide guidance and training on the mechanism and development of a cooperative. These agencies also provide assistance to cooperatives through related programs and facilities. The development of cooperatives using this approach, has been consistent and it involves two types of development pattern: the general development and cooperative development.

As the first pattern, the general development is a conventional model that depends completely on the society for the growth of the cooperatives. The government's role is merely to provide managerial guidance and control. This is in contrast with the second pattern, the cooperative development, which is a model where the government provides special loans or other financial incentives to cooperatives. Particularly in the WestBandung regency, the ongoing programs which aim to develop cooperatives involve knowledge and skill enhancement, especially about cooperative institutions, know-how, and advice on how a cooperative can function, grow, and survive.

According to the Cooperative Law Number 25, 1992, experts and practitioners are encouraged to provide training and motivational development for cooperative members so that they will always be motivated and can independently, run the cooperatives on their own as well as increase their members' revenues. These targets can be achieved by cooperating with practitioners and high-achiever cooperatives that have gained national recognition and reputation. Further assistance to be provided can be in the form of developing members' knowledge in building up the cooperative society and in improving human resources. Both these knowledge can serve as a solid ground for the cooperative society's economic development. Another way to achieve the targets is to hold informal meetings among members who can use these meetings as a platform for sharing.

The second approach is a theoretical one which has been implemented. This approach concerns the cooperative's endurance or performance or sustainability. Based on the Law Number 25, 1992, a viable cooperative is one that can increase the quantity of its member, capital and operational business volume as well as offer better service for its members. The increase in performance is not isolated, that is, the increasing number of members has to be in line with the increasing operational business volume and also with the increasing capital to be invested further. Additional facilities are further increased through the availability of social funds as a privilege for being a cooperative member.

As what have been proposed by Sharma and Ruud (2003), a sustainable organization is one that is influenced by three factors: economic, social, and environmental. The economic factor is to increase the business in the organization. The social factor is to see what kind of social responsibility, which aims to help not only people inside but also outside the organization, is being organized by the organization. Finally, the environmental factor which involves internal and external aspects of the organization which can influence each other in achieving strategic goals.

Despite being operated according to appropriate measures, there are still existing problems with regards to the sustainability or the survival of cooperatives. Hence, with the issues underlying the study based on the 
phenomenon that has been described, this paper will examine with depth the sustainability of cooperatives according to the scientific views of entrepreneurial management. This is based on entrepreneurial personality, entrepreneurial intention and value creation.

\section{Literature Study}

Law Number 25, 1992 defines a cooperative as "a cooperative is a business institution that consists of persons or legal cooperative institutions whose activity is based on cooperative principles, and the aforementioned business institution simultaneously acts as the society's economic movement based on communal principles." According to OECD, sustainability means "connecting a balanced economic, social, and societal environment" and "the consequence of today's activity that meets the challenges of sustainable development and that requires the decisions achieved and informed by various possibilities pertaining to public consequences and responsibilities" (Farneti \& Guthrie, 2009; Mohrman \&Worley, 2010). Therefore, the indicators of each variable are:

- Cooperative performance is defined as "the degree of accomplishment" or performance is the degree of achievement of an organization (Keban, 2000; Farneti \& Guthrie, 2009; Mohrman \& Worley, 2010): the increasing of membership, capital, size of the business, and service quality to member and society.

- Entrepreneurial Personality is the crucial impact on the company's success in practice when managed by several persons or employees (Bezzina, 2010): achievement, locus of control, ambiguity tolerance, risk taking, personal value, education, experience, and opportunity recognition.

- Entrepreneurial Intention is deemed as a bias of personal intent; someone who sees inventions in $\mathrm{him} /$ herself as an interesting and desirable business (Shapero \& Sokol, 1982); it is adapted from the theory of reasonable action from (Fishbein \& Ajzen ,1975): attitude toward entrepreneurship, social norm, perceived behavioral control, self efficacy.

- Value Creation: it is difficult to separate the definition between the creation of new values and innovation. Successful innovation, whether it is technical, commercial or organisational, always becomes the source of new values (Schumpeter, 1934): new ideas, new products, reform the company.

\section{Research Method}

The study was conducted in the West Bandung regency and it focuses on consumer cooperatives. Selection was made using purposive sampling method. The consideration of this study is based on the variables of entrepreneurial personality, entrepreneurial intention and value creation. The samples, drawn from data released in 2013 by DISPERINDAGKOP and UMKM, comprise 823 units of cooperatives spread around the West-Bandung regency. Of the total, 150 units of consumer cooperatives have capital ranging from 100 million to 1 billion rupiahs. These were considered as adequate to be chosen as research samples.

Data for this study were gathered through: (i) structured interviews which were based on a list of questions (questionnaires) that were designed to extract various types of primary data, (ii) in-depth interviews of personnels including consumption cooperative managers, (iii) observations which were done in the research field as a means of detect the internal and external situation of the consumer cooperatives, and also to have a better idea of the problems currently faced and (iv) documentations provided by secondary data sources or government related institutions. Data were then analyzed using Structural Equation Model (SEM). The aim is to examine whether the variables affect the cooperative's performance and to determine their direct or indirect total impact. 


\section{Results and Discussion}

By using Structural Equation Modeling and AMOS 16 software, the result of the SEM analysis can be seen in the following figure:

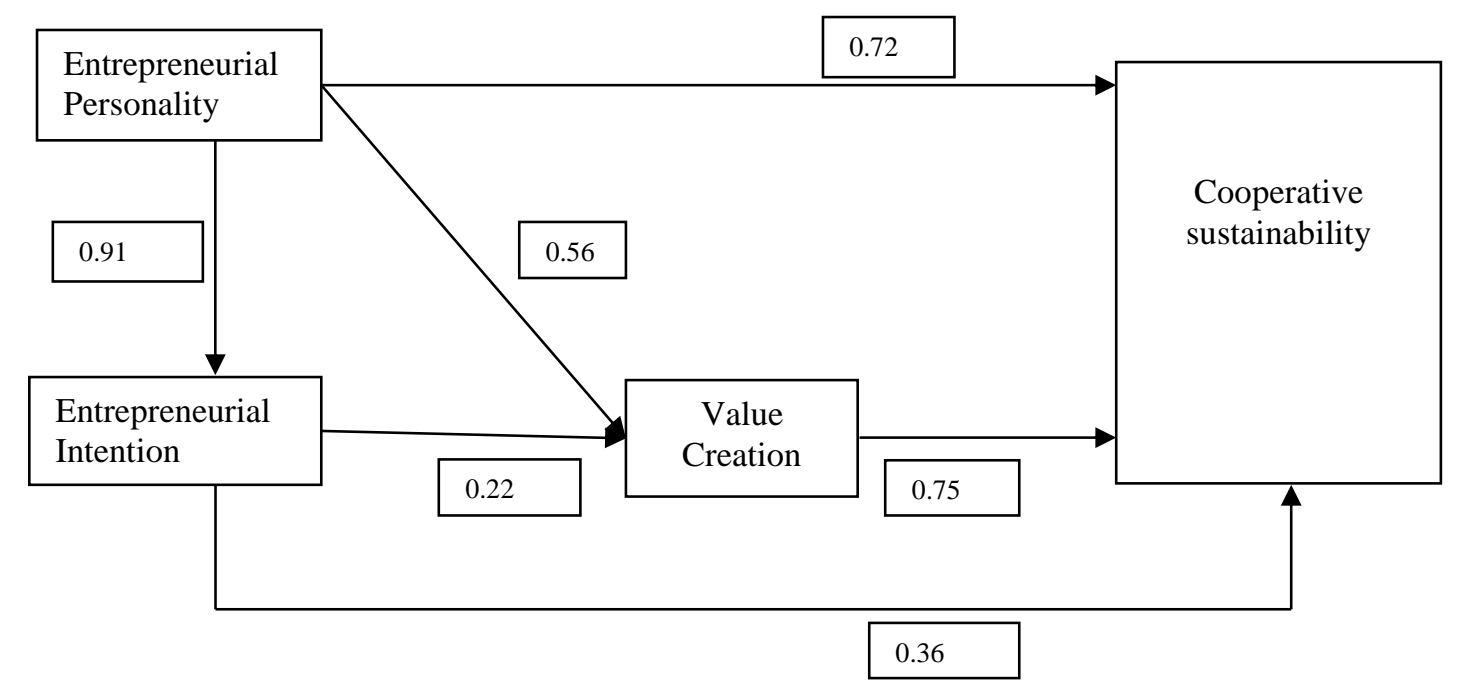

Figure 1. Results of Analysis

The above SEM analysis answers the following hypotheses:

1. There is an influence of entrepreneurial personality, entrepreneurial intention and value creation on the cooperative's sustainability.

These three variables are important for improving the cooperative's sustainability which include increasing the number of members, capital, business volume, and services to members and community.

2. There is an influence of entrepreneurial personality on entrepreneurial intention.

Entrepreneurial personality relates to entrepreneurial intention and this serves as the basis of someone's personality with the top four indicators being: achievement, locus of control, ambiguity tolerance, and risk-taking. All of these can enhance entrepreneurial intention which is meant to create a desire for molding the attitude toward entrepreneurship and self-efficacy within the individual persons.

3. There is an influence of entrepreneurial personality on value creation.

Entreperenurial personality influence the value creation through four top indicators which are: achievment, locus of control, ambiguity tolerance and taking the risk to make something new.

4. There is an influence of entrepreneurial intention on value creation.

Entrepreneurial intention can influence value creation mainly through the attitude indicator toward entrepreneurship.

5. There is an influence of entrepreneurial personality on cooperative sustainability.

Entrepreneurial personality has a direct and positive influence on cooperative sustainability and the influence is accomplished through value creation.

6. There is an influence of entrepreneurial intention on cooperative sustainability.

Entrepreneurial intention influence cooperative sustainability through moderating value creation and influencing directly, where the new creation is to improve cooperative sustainability. Value creation with innovation and creation can increase the additional number of members, especially in the capitalization of cooperatives. 


\section{Conclusion}

This study offers empirical contribution which shows the agreement and support between the results obtained and the proposed hypotheses. The results answer all the hypotheses. In general, the conclusion that can be obtained from this study is as follow:

1. The highest influence is found in the variable, Entrepreneurial Personality on Entrepreneurial Intention. This is very likely to happen when it concerns the presence of a person's intention as an impact of the company's performance in this case, the cooperatives.

2. The lowest influence is found in the variable, Entrepreneurial Intention on Value Creation.

Cooperative sustainability is supposed to increase for all the members, especially the welfare of the members in accordance with the vision of the cooperatives. Based on the outcome of this study, it is strongly advised that the regional government facilitate and guide the process of cooperative sustainability by holding formal programs which can be implemented through guided consultaions about cooperative management or through seminars, workshops and training.

\section{Acknowledgements}

We thank Intan Sakti and Batu Mardohar for the assistance provide in particular the technique and methodology which has greatly improved the manuscript. We also thank our colleagues from Widyatama University and Universitas Pendidikan Indonesia for their support.

\section{References}

Barney, J.B., (1986a). Strategic Factor Markets: Expectations, Luck and Business Strategy. Management Science, 32, $1231-1241$.

Barney, J. (1991). Firm Resources and Sustained Competitive Advantage. Journal of Management, 17(1), 99-120.

Bezzina, F. (2010). Characteristics of the Maltase Entrepreneur. International Journal of Arts and Sciences 3(7), 292 312.

Drucker, P. F. (1994). Innovation and Entrepreneurship, Practice and Principles. Jakarta Gelora Aksara. Erlangga.

Ferdinand, A. (2002). Structural Equation Modeling Dalam Penelitian Manajemen: Aplikasi Model-Model Rumit Dalam Penelitian untuk Tesis Magister dan Disertasi Doktor, Edisi 2, Semarang: BP Undip.

Farneti, F., \& Guthrie, J. (2009). Sustainability reporting by Australian public sector organisations: Why they report. Accounting Forum, 33, 89-98. http://dx.doi.org/10.1016/j.accfor.2011.06.004

Fishbein, M. \& Ajzen, I. (1975). Belief, attitude, intention and behavior: An introduction to theory and research. Reading, MA: Addison-Wesle.

Keban, Y. T. (2000). Good Governance dan Capacity Building sebagai Indikator Utama dan Fokus Penilaian Kinerja Pemerintahan. Jakarta: Capacity Building for Local Governance Bappenas.

Man, T. W.Y. and Chan, K.F., Lau, T., (1997). The Entrepreneurial Personality Small Business Owner Managers in Hong Kong: A Critical Incident Analysis. Journal of Enterprising Culture 5(3), 249-271.

Mohrman, S. A., \& Worley, C. G. (2010). The organizational sustainability journey: Introduction to the special issue. Organizational Dynamics, 39(4), 289-294.

Naman, J. L. \& Dennis P. S. (1993). Entrepreneurship and The Concept of Fit: A Model and Empirical Tests. Strategic Management Journal 14(2), 137-153

Porter, M.E. (1998). Competitive Advantage, Creating and Sustaining Superior Performance, With a New Introduction, New York: The Free Press.

Scarborough, N.M. and Zimmerer, T.W. (1993). Effective Small Business Management, New York:Mc Millan.

Sekaran, U., (2003). Research Methods for Business, New York: John Willey and Sons, Inc.

Sharma, S., \& Ruud, A. (2003). On the path to sustainability: Integrating social dimensions into the research and practice of environmental management. Business Strategy and the environment, 12(5), 205-214. http://dx.doi.org/10.1002/bse.366

Suryana. (2013). Kewirausahaan, Pedoman Praktis: Kiat dan Proses Menuju Sukses. Jakarta: Salemba Empat. 
Shapero, A., and Sokol, L. (1982). 'The Social Dimensions of Entrepreneurship', in C. Kent, D. Sexton, and K. H. Vesper (eds.) The Encyclopedia of Entrepreneurship. Englewood Cliffs, NJ: Prentice-Hall. 72-90.

Schumpeter, J.A. (1934). The Theory of Economic Development, Cambridge, Mass.: Harvard University Press (originally published in German in 1911; reprinted by Transaction Publishers, New Brunswick, New Jersey in 1997).

Indonesia Law Number 25, 1992, Cooperatives and Micro Small Business Entreprises. 